\title{
Standardized ileal digestible isoleucine requirement for laying hens
}

\author{
J.W. Spek \\ Wageningen Livestock Research
}

CVB Documentation report nr. 74 June 2018

Wageningen Livestock Research

P.O. Box 338

$6700 \mathrm{AH}$ Wageningen

The Netherlands 


\section{(c) Federatie Nederlandse Diervoederketen 2017}

No part of this edition may be copied, photocopied, reproduced, translated or reduced to any electronic medium or machine-readable form, in whole or in part, without specific written permission of the Federatie Nederlandse Diervoederketen (info@diervoederketen.nl).

All copyrights and database rights with respect to this publication are expressly reserved. Nothing in this publication may be reproduced, copied, retrieved, made public or re-used or made available in any way whatsoever to third parties by way of printing, photocopying, microfilm or in any other way unless the Federatie Nederlandse Diervoederketen has given express written permission to do so. This publication has been compiled with great care; however, the Federatie Nederlandse Diervoederketen and Wageningen Livestock Research cannot be held liable in any way for the consequences of using the information in this publication. 


\section{Preface}

In 2017 a new Table has been introduced called; Table 'Standardized ileal digestibility of amino acids in feedstuffs for poultry' and has been described in the CVB Documentation report $\mathrm{nr}$. 61. As a feed evaluation system has two pillars - the supply of nutrients by the diet on the one hand and the requirement for these nutrients by the animals on the other hand (both expressed in the same units) - it was also necessary to also update and express the amino acid requirements on a standardized ileal digestibility (SID) basis.

Therefore a large meta-analysis dataset was constructed from studies in which amino acid requirements in laying hens were estimated. The SID amino acid concentrations of the diets used in these studies were recalculated based on the new CVB SID amino acid Table presented in CVB documentation report $\mathrm{nr} .61$ and the requirement for SID isoleucine was subsequently estimated. The results of this meta-analysis for standardized ileal digestible isoleucine (SID-ILE) requirement are presented in the present CVB Documentation report. Compared to the former CVB apparent faecal digestible ILE recommendation for laying hens described in CVB Documentation report nr. 18 and published in 1996 the present established SID-ILE amino acid recommendations for laying hens are:

1. Based on a larger dataset of requirement studies

2. Based on studies with modern laying hen types in the period $1990-2017$

3. Based on standardized ileal digestible amino acid values in feedstuffs instead of apparent faecal digestible amino acid values.

The in this report estimated requirements of SID-ILE will be incorporated in the Dutch CVB Tabellenboek Veevoeding Pluimvee 2018 and in the English version CVB Table Poultry Nutrition 2018.

This study was guided and assessed by the Technical Committee of CVB and the Ad hoc group 'SID amino acid requirements for laying hens'

Wageningen, June 2018

J.W. Spek 


\section{Members of the Technical Committee of the CVB}
M. Rijnen (chair)
J. Fledderus
B. Boswerger
A. Dijkslag
H. van Laar
K. Geerse
D. van Manen
J. van der Staak
H. Korterink
A. van de Ven
C. van Vuure
G. van Duinkerken

J.W. Spek
Nederlandse Vereniging Diervoederindustrie (Nevedi)

Nederlandse Vereniging Diervoederindustrie (Nevedi)

Nederlandse Vereniging Diervoederindustrie (Nevedi)

Nederlandse Vereniging Diervoederindustrie (Nevedi)

Nederlandse Vereniging Diervoederindustrie (Nevedi)

Nederlandse Vereniging Diervoederindustrie (Nevedi)

Overleggroep Producenten Natte Veevoeders (OPNV)

Land- en Tuinbouworganisatie Nederland (LTO)

Nederlandse Vereniging van Handelaren in Stro, Fourages en Aanverwante Producten (HISFA)

Nederlandse Vereniging Diervoederindustrie (Nevedi)

MVO, ketenorganisatie voor oliën en vetten

Wageningen Livestock Research, Dept. Animal Nutrition, Wageningen

Wageningen Livestock Research, Dept. Animal Nutrition, Wageningen

\section{Members of the Ad hoc group 'SID amino acid requirements for laying hens'}
A. Dijkslag
M. van Erp
K. Geerse
A. de Ruijter
J.W. Spek
B. Swart

ForFarmers, Lochem

De Heus, Ede

Trouw Nutrition, Amersfoort

De Hoop, Zelhem

Wageningen Livestock Research, Wageningen

Agrifirm, Apeldoorn 


\section{Contents}

Table of Contents

Page

Preface

3

Members of the Technical Committee of the CVB ……................................................ 4

Members of the Ad hoc group 'SID amino acid requirements for laying hens' ...................... 4

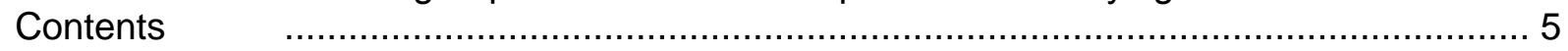

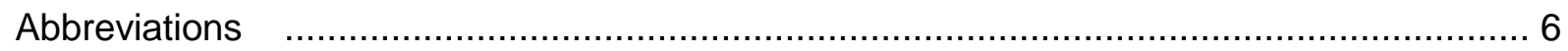

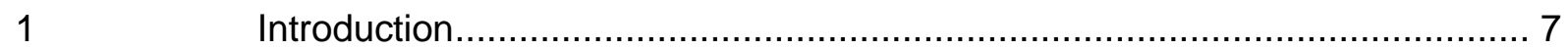

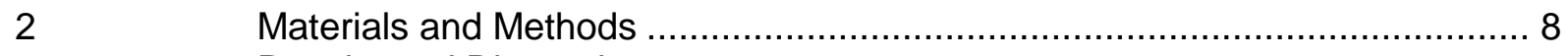

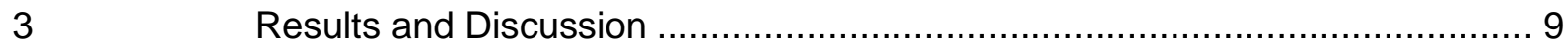

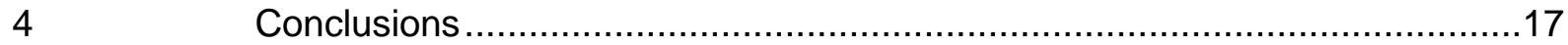

List of studies included in the meta-analysis ..............................................................18

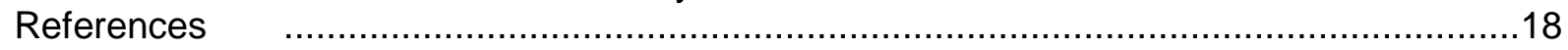

Appendix A. Relationship between dietary SID-ILE supply and performance parameters FCR and EM for the various titration trials including the estimated SID-ILE requirements based on the quadratic broken-line model.....

Appendix B. SID-ILE model estimates for minimum FCR and maximum EM .....................31 


\section{Abbreviations}

$\begin{array}{ll}\text { AA } & \text { Amino acids } \\ \text { AFD } & \text { Apparent faecal digestible } \\ \text { ARG } & \text { Arginine } \\ \text { BW } & \text { Body weight } \\ \text { BWG } & \text { Body weight gain } \\ \text { CP } & \text { Crude protein } \\ \text { CYS } & \text { Cysteine } \\ \text { EM } & \text { Egg mass } \\ \text { FCR } & \text { Feed conversion ratio } \\ \text { ILE } & \text { Isoleucine } \\ \text { LYS } & \text { Lysine } \\ \text { Max } & \text { Maximum value } \\ \text { ME } & \text { Metabolic energy } \\ \text { MElh } & \text { Metabolic energy for laying hens } \\ \text { MET } & \text { Methionine } \\ \text { Min } & \text { Minimum value } \\ \text { M+C } & \text { Methionine plus Cysteine } \\ \text { N } & \text { Number } \\ \text { R } & \text { Coefficient of determination } \\ \text { Req. } & \text { Requirement } \\ \text { SID } & \text { Standardized ileal tract digestible } \\ \text { Std. Dev. } & \text { Standard deviation } \\ \text { Std. Err. } & \text { Standard error } \\ \text { THR } & \text { Threonine } \\ \text { TRP } & \text { Tryptophan } \\ \text { VAL } & \text { Valine } \\ \text { \%CV } & \text { Coefficient of variation } \\ & \end{array}$




\section{Introduction}

In 2012 a large meta-analysis was carried out by van Krimpen and others in order to determine the dietary requirements for standardized ileal tract digestible (SID) amino acids (AA) for laying hens. This study resulted in a report published by van Krimpen et al. (2015). Before the start of this meta-analysis another large meta-analysis was carried out in order to determine the SID-AA levels for the various feed ingredients. This meta-analysis resulted in a CVB table with SID-AA concentrations for the various feed ingredients and this Table was used by van Krimpen et al. (2015) in order to recalculate the dietary SID-AA levels for the individual AA titration studies in order to estimate AA requirements. However, in 2017 this CVB Table has been updated with new data published in the years between 2012 and 2017 as there were questions about the SID cysteine digestibility value for soybean meal. As a result, not only the SID-AA values for soybean meal have been updated but also for other feedstuffs. As a consequence it was necessary to recalculate all the diets used in the AA titration studies that van Krimpen et al. (2015) used to determine AA-requirements. In this study the results of estimated dietary SID isoleucine (SID-ILE) requirements based on the new Table values as presented in CVB documentation report nr. 61 are presented. Furthermore, the dataset used by van Krimpen et al. has been extended with new studies that were not included in the study of van Krimpen et al..

Furthermore, compared to the study of van Krimpen another model for estimation of SID-ILE requirements has been used. This model consisted of a quadratic broken-line model as described and used in the estimation of SID-LYS requirements for laying hens as well (CVB documentation report nr. 69). 


\section{Materials and Methods}

Isoleucine requirement studies were selected from literature $(1990-2017)$ in which the dietary ILE content was varied by means of addition of graded levels of dietary synthetic ILE. Furthermore, performance characteristics such as egg mass (EM: $g / d / h e n)$ and feed conversion ratio (FCR; $g$ feed : $g$ egg mass) had to be recorded and information with respect to dietary composition and age of the laying hens had to be provided in the studies. The apparent faecal digestible (AFD) non-test-AA : AFD-LYS ratios needed to be at least $90 \%$ of the CVB (2012) requirement level and the basal AFD-ILE : AFD-LYS ratio needed to be at least $20 \%$ below the CVB (2012) AFD-ILE : AFD-LYS requirement level.

Ass well, also studies were considered in which the ILE requirement was investigated based on summit and dilution diets that were mixed in various ratios in order to obtain the desired differences in ILE.

Requirements were estimated using a quadratic broken-line model as described below. This model was adopted from a publication of Robbins et al. (2006).

The quadratic broken-line model is as follows:

If (SID-ILE $(\%)<R)$ then EM or FCR $=\mathrm{L}+\mathrm{U} \times(\mathrm{R}-\mathrm{SID} \text {-ILE })^{\wedge}$;

Else $\mathrm{EM}$ or $\mathrm{FCR}=\mathrm{L}+\mathrm{U} \times 0$;

Where:

$\mathrm{L}=$ plateau value for $\mathrm{EM}$ or FCR

$\mathrm{R}=$ break-point value for SID-ILE (\%)

$\mathrm{U}=$ slope value, representing the increase in EM or decrease in FCR per unit increase in dietary SID-ILE.

Estimated SID-ILE requirements for EM and FCR were regressed against factors such as EM, FCR, age, and the dietary factors CP, ME and CP : ME ratio. Unfortunately, it was not possible to also include body weight as a variable due to lack of information. 


\section{Results and Discussion}

In Table 1. Some characteristics of the studies included in the meta-analysis is given. The dataset consisted of 7 studies with in total 16 trials and 100 observations. Of these studies, 4 studies (including 9 trials) were titration trials whereas the other studies consisted of summit and dilution diets.

In Appendix A for each trial the relationship between dietary SID-ILE (\%) and FCR and between dietary SID-ILE (\%) and EM is presented graphically together with the estimated SID-ILE requirements for the quadratic broken-line model.

In Appendix $B$ the estimated quadratic broken-line model parameters for each titration trial is given. In some cases (for trials 1, 3, 10,11,12, 15 and 16) also model estimates are provided after removing the basal treatment (or the treatment with the lowest SID-ILE content) as it was expected that for these trials this would significant affect model estimates of $\mathrm{R}$ (or requirement estimates for SID-ILE). The model predictions for these trials were the basal treatment was removed prior to fitting the model are shown with the letter "a" (for example; trial 1 becomes trial 1a).

For a number of titration trials it was not possible to estimate (unique) SID-ILE requirements for maximum EM (for trials 3, 4, 5, 6, 7 and 9) and for minimum FCR (for trials 1, 2, 3, 4, 5, 6, 7,9 , and 14). Especially with respect to estimation of SID-ILE requirement for minimum FCR few titration trials allowed for estimation of a requirement. With respect to estimation of SIDILE requirements for FCR it also seemed that in a number of cases birds had a negative energy balance complicating the possibility to estimate reliable SID-ILE requirements for FCR. Therefore, in this study the focus is on establishing SID-ILE requirements for maximum EM. Furthermore, for the dilution studies optimal SID-ILE concentrations for maximum EM were estimated at high dietary SID-LYS intake levels $(1.01 \% ; 1156 \mathrm{mg} / \mathrm{d})$ and dietary concentrations of dietary protein (on average19.8\%). As these high dietary SID-LYS and high dietary protein concentrations are not used in practice it might be undesirable to translate these results to practice.

The titration results from trials 1, 2, 3, 4, 5, 6 and 7 (studies from Peganova and Eder; 2002 and 2003) indicate that an oversupply of dietary SID-ILE reduces EM and should be prevented. For trials 4, 5, 6 and 7 the lowest dietary SID-ILE treatment resulted in the highest EM yield. It is, therefore, unknown what the optimal SID-ILE concentration would have been in trials 4, 5, 6 and 7. Probably these optimal SID-ILE concentrations would be lower than the basal SID-ILE level.

In Table 2 the average estimated optimal SID-ILE concentrations and SID-ILE intake statistics for maximum EM are presented in which is distinguished between titration trials and dilution diets. 
Table 2. Estimated optimal SID-ILE requirements (as \% and as daily intake) for maximum egg mass (EM).

\begin{tabular}{|c|c|c|c|c|c|c|c|}
\hline & Parameter & $\mathrm{N}^{*}$ & Mean & Std. Dev. & Min. & $\operatorname{Max}$ & $\% \mathrm{CV}$ \\
\hline \multirow[t]{3}{*}{ SID-ILE (\%) } & Titration* & 9 & 0.531 & 0.0970 & 0.417 & 0.685 & 18.3 \\
\hline & Dilution $^{* *}$ & 12 & 0.554 & 0.0635 & 0.494 & 0.708 & 11.5 \\
\hline & Dilution $^{\star \star \star}$ & 9 & 0.541 & 0.0431 & 0.495 & 0.630 & 8.0 \\
\hline \multirow{3}{*}{$\begin{array}{l}\text { SID-ILE } \\
\text { intake (mg/d) }\end{array}$} & Titration* & 9 & 608 & 92.0 & 461 & 758 & 15.1 \\
\hline & Dilution $^{\star *}$ & 12 & 634 & 94.2 & 474 & 772 & 14.9 \\
\hline & Dilution ${ }^{\star \star *}$ & 9 & 636 & 89.0 & 474 & 759 & 14.0 \\
\hline \multirow{3}{*}{$\begin{array}{l}\text { SID-ILE } \\
\text { intake per } \mathrm{g} \\
\text { of EM }(\mathrm{mg} / \mathrm{g})\end{array}$} & Titration* & 9 & 11.1 & 1.56 & 8.6 & 13.0 & 14.1 \\
\hline & Dilution $^{\star \star}$ & 12 & 12.9 & 2.01 & 9.4 & 17.0 & 15.6 \\
\hline & Dilution*** & 9 & 12.3 & 1.60 & 9.4 & 14.9 & 13.0 \\
\hline \multirow{3}{*}{$\begin{array}{l}\text { SID-ILE:SID- } \\
\text { LYS ratio }\end{array}$} & Titration ${ }^{*}$ & 9 & 91.3 & 13.93 & 69.3 & 117.8 & 15.3 \\
\hline & Dilution** & 12 & 55.5 & 6.50 & 49.4 & 69.5 & 11.7 \\
\hline & Dilution $^{\star \star \star}$ & 9 & 56.8 & 7.16 & 49.4 & 69.5 & 12.6 \\
\hline \multirow{3}{*}{$\begin{array}{l}\text { SID-ILE:SID- } \\
\text { LYS ratio**** }\end{array}$} & Titration* & 9 & 91.4 & 13.90 & 69.3 & 117.8 & 15.2 \\
\hline & Dilution $^{\star *}$ & 12 & 99.7 & 20.46 & 75.4 & 133.7 & 20.5 \\
\hline & Dilution $^{\star \star *}$ & 9 & 91.5 & 14.50 & 75.4 & 113.8 & 15.9 \\
\hline
\end{tabular}

* number of titration trials (total number of titration trials is 9 ( 8 trials +1 titration trials for which $\mathrm{R}$ values were estimated again after excluding the diet containing the lowest dietary SID-ILE level). For trials 4, 5, 6 and 7 the lowest observed dietary SID-ILE level was used.

${ }^{* *}$ number of dilution trials (total number of dilution trials is 12 ( 7 dilution trials +5 dilution trials for which $R$ values were estimated again after excluding the diet containing the lowest dietary SID-ILE level).

${ }^{* * *}$ number of dilution trials (total number of dilution trials is 9 ( 5 dilution trials +4 dilution trials for which $R$ values were estimated again after excluding the diet containing the lowest dietary SID-ILE level). Dilution trials 12 and 13 were excluded because of the low maximum observed rate of lay of 75 and 71 percent, respectively.

${ }^{* * * *}$ This ratio is calculated using formula [F8] in CVB Documentation report nr. 69 to predict SID-LYS requirement. In case the formula [F8] resulted in a lower SID-LYS requirement than the observed SIDLYS intake at which maximum EM was estimated, then this formula was used to calculate the SIDILE:SID-LYS ratio, otherwise the observed SID-LYS intake at which maximum EM was estimated was used.

Results in Table 2 show a wide range in optimal estimated SID-ILE concentrations and optimal SID-ILE intake levels. Because of the high dietary concentrations of protein and lysine in the dilution trials that corresponded with the estimated SID-ILE requirements that are substantially higher than used in practise it was decided to focus on the results of the titration trials. In Table 2 the average estimated SID-ILE requirements are shown. As the results of the individual titration trials in Appendix $A$ and $B$ shows, in a number of cases it is difficult or even impossible to estimate reliable SID-ILE requirements. Therefore, it was also chosen to consider the observed SID-ILE intake levels at which maximum EM production was observed. In case the SID-ILE requirements of the titration studies were based on the observations with the highest EM the average SID-ILE:SID-LYS requirement was $90 \pm 19.4 \%$ and SID-ILE : EM ratio $10.3 \pm 1.98 \mathrm{mg} / \mathrm{g}$.

An average observed dietary SID-ILE requirement of $10.3 \mathrm{mg} / \mathrm{g}$ EM corresponds better with optimal dietary ILE requirements per $g$ of EM as estimated by Huyghebaert et al. (1991) and Mannion et al. (1993) than the average model estimated SID-ILE requirement of $11.1 \mathrm{mg}$ SID-ILE per g of EM. Huyghebaert et al. (1991) estimated an ILE requirement of $44.47 \mathrm{mg} / \mathrm{kg}$ body weight and $9.48 \mathrm{mg}$ per $\mathrm{g}$ of EM. Mannion et al. (1991) estimated an ILE requirement of 
$33.56 \mathrm{mg} / \mathrm{kg}$ body weight and $9.91 \mathrm{mg}$ per $\mathrm{g}$ of EM. The average calculated SID digestibility of ILE in both the study of Huyghebaert et al. (1991) and Mannion et al. (1991) was 84\%. Converting from total to SID level his means that the relationships observed by Huyghebaert et al. and Mannion et al. are as follows: for Huyghebaert et al.; $37.4 \mathrm{mg} / \mathrm{kg}$ body weight and $7.96 \mathrm{mg}$ per $\mathrm{g}$ of EM and for Mannion et al.; $28.2 \mathrm{mg} / \mathrm{kg}$ body weight and $8.32 \mathrm{mg}$ per $\mathrm{g}$ of EM. In 8 of the 9 titration trials in the present study Lohman Brown laying hens were used that produced an average maximum EM of $55.6 \mathrm{~g} / \mathrm{d}$. Assuming a body weight of $1.9 \mathrm{~kg}$ this would mean SID-ILE requirements of 9.2 and $9.3 \mathrm{mg}$ per $\mathrm{g}$ EM according to the studies of Huyghebaert and Mannion, respectively.

In Table 3 the estimated optimal SID-ILE requirements for maximum EM is given expressed in $\mathrm{mg} / \mathrm{d}$ and as a percentage of the diet for maximum EM at various egg production rates based on SID-ILE requirements of $10.3 \mathrm{mg}$ per $\mathrm{g}$ of EM produced.

Table 3. Estimated optimal SID-ILE requirements for maximum EM expressed in $\mathrm{mg} / \mathrm{d}$ and as a percentage of the diet for maximum EM at various egg production rates based on SIDILE requirements of $10.3 \mathrm{mg}$ per gram of EM produced. The calculated feed intake required for an average egg weight of $60 \mathrm{~g}$ and at egg production rates of 90 and $95 \%$ are based on the assumptions presented as a footnote $\left(^{*}\right)$ underneath this Table.

\begin{tabular}{|c|c|c|c|c|c|c|c|c|c|c|}
\hline \multirow[b]{3}{*}{ BW (kg) } & \multicolumn{2}{|c|}{$\begin{array}{r}\text { Feed intake } \\
(\mathrm{g} / \mathrm{d}) \\
\end{array}$} & \multicolumn{2}{|c|}{$\begin{array}{r}\text { Egg mass } \\
(\mathrm{g} / \mathrm{d})\end{array}$} & \multicolumn{2}{|c|}{$\begin{array}{r}\text { SID-ILE } \\
(\mathrm{mg} / \mathrm{d})\end{array}$} & \multicolumn{2}{|c|}{$\begin{array}{r}\text { Dietary SID- } \\
\text { ILE (\%) }\end{array}$} & \multicolumn{2}{|c|}{$\begin{array}{l}\text { SID-ILE:SID- } \\
\text { LYS ratio** }\end{array}$} \\
\hline & \multicolumn{10}{|c|}{ Egg production rate (\%) } \\
\hline & 90 & 95 & 90 & 95 & 90 & 95 & 90 & 95 & 90 & 95 \\
\hline 1.5 & 112 & 115 & 54 & 57 & 556 & 587 & 0.498 & 0.512 & 76 & 74 \\
\hline 1.6 & 114 & 117 & 54 & 57 & 556 & 587 & 0.486 & 0.500 & 76 & 74 \\
\hline 1.7 & 117 & 120 & 54 & 57 & 556 & 587 & 0.475 & 0.489 & 76 & 74 \\
\hline 1.8 & 120 & 123 & 54 & 57 & 556 & 587 & 0.465 & 0.478 & 76 & 74 \\
\hline 1.9 & 122 & 125 & 54 & 57 & 556 & 587 & 0.455 & 0.468 & 76 & 74 \\
\hline 2.0 & 125 & 128 & 54 & 57 & 556 & 587 & 0.445 & 0.459 & 76 & 74 \\
\hline
\end{tabular}

*Feed intake is calculated based on: a feed with a MElh content of $11.8 \mathrm{MJ} / \mathrm{kg}$, a requirement of $12.1 \mathrm{~kJ}$ per g egg mass, a maintenance requirement of $435 \mathrm{~kJ} M E$ per $\mathrm{kg} \mathrm{MBW}\left(\mathrm{BW}^{\wedge} 0.75\right)$, a requirement of $21.5 \mathrm{~kJ} \mathrm{ME}$ per gram BWG, a daily BWG of $1.5 \mathrm{~g}$, and $9.5 \mathrm{~kJ}$ ME per kg BW per unit decrease in ${ }^{\circ} \mathrm{C}$ below $25^{\circ} \mathrm{C}$ and a daily temperature of $22{ }^{\circ} \mathrm{C}$.

${ }^{* *}$ The optimal SID-ILE:SID-LYS ratio for maximum EM is calculated based on the ratio between SID-ILE intake (SID-ILE requirements calculated as $10.3 \mathrm{mg}$ per gram of EM produced) and SID-LYS intake which is based on formula [F8] described in CVB Documentation report nr. 69. 
Table 1. Summary of the total dataset

\begin{tabular}{|c|c|c|c|c|c|c|c|c|c|c|c|c|}
\hline Study & Trial & Breed & $\begin{array}{c}\text { Starting } \\
\text { Age } \\
\text { (weeks) }\end{array}$ & $\begin{array}{l}\text { Duration of } \\
\text { experiment } \\
\text { (weeks) }\end{array}$ & $\begin{array}{l}\text { Dietary } \\
\text { CP (\%) }\end{array}$ & $\begin{array}{c}\text { Max } \\
\text { obs. } \\
\text { rate of } \\
\text { lay (\%) }\end{array}$ & $\begin{array}{l}\text { Max } \\
\text { obs. } \\
\text { egg } \\
\text { mass }\end{array}$ & $\begin{array}{c}\text { Max } \\
\text { obs. } \\
\text { feed } \\
\text { intake }\end{array}$ & $\begin{array}{l}\text { Min } \\
\text { SID- } \\
\text { ILE } \\
(\%)\end{array}$ & $\begin{array}{l}\text { Max } \\
\text { SID- } \\
\text { ILE } \\
(\%)\end{array}$ & $\begin{array}{c}\text { Max. } \\
\text { FCR } \\
\text { minus } \\
\text { Min. FCR }\end{array}$ & $\begin{array}{c}\text { Max. egg } \\
\text { mass } \\
\text { minus Min. } \\
\text { egg mass }\end{array}$ \\
\hline \multirow[t]{2}{*}{ Peganova and Eder (2002) } & 2 & Lohman Brown & 24 & 9 & 13.2 & 98 & 58 & 117 & 0.333 & 1.013 & 0.190 & 9.6 \\
\hline & 3 & Lohman Brown & 46 & 9 & 13.2 & 91 & 57 & 115 & 0.333 & 1.013 & 0.170 & 9.6 \\
\hline \multirow{3}{*}{ Peganova and Eder (2003) } & 4 & Lohman Brown & 25 & 3 & 11.4 & 94 & 52 & 115 & 0.486 & 1.066 & 0.230 & 11.9 \\
\hline & 6 & Lohman Brown & 25 & 3 & 11.4 & 98 & 56 & 130 & 0.486 & 1.066 & 0.230 & 16.6 \\
\hline & 7 & Lohman Brown & 25 & 3 & 11.4 & 97 & 57 & 130 & 0.486 & 1.066 & 0.370 & 5.3 \\
\hline Shivazad et al. (2002)* & 8 & Hy-line W36 & 35 & 8 & $10-14$ & 89 & 50 & 91 & 0.373 & 0.540 & 0.300 & 16.2 \\
\hline Carvalho Mello et al. (2012) & 9 & Hy-Line W36 & 42 & 16 & 15.3 & 83 & 53 & 94 & 0.556 & 0.753 & 0.052 & 1.5 \\
\hline \multirow{3}{*}{ Mannion et al. (1993)* } & 10 & Hy-Line & 42 & 4 & $11-28$ & 85 & 52 & 121 & 0.253 & 0.745 & 2.078 & 30.9 \\
\hline & 11 & Tegel & 42 & 4 & $11-28$ & 86 & 50 & 116 & 0.253 & 0.745 & 2.427 & 32.5 \\
\hline & 12 & Hy-Line & 66 & 4 & $11-28$ & 75 & 45 & 111 & 0.238 & 0.728 & 2.236 & 29.4 \\
\hline Dong et al. (2016) & 14 & Lohman Brown & 28 & 12 & 14.5 & 94 & 58 & 113 & 0.515 & 0.915 & 0.102 & 1.4 \\
\hline \multirow{2}{*}{ Huyghebaert et al. (1991)* } & 15 & ISA Brown & 32 & 4 & $11-20$ & 90 & 57 & 125 & 0.290 & 0.594 & 1.081 & 20.1 \\
\hline & 16 & ISA Brown & 52 & 4 & $11-20$ & 82 & 55 & 130 & 0.290 & 0.594 & 1.087 & 18.2 \\
\hline
\end{tabular}

${ }^{*}$ Studies with an asterix are dilution studies meaning that AA other than ILE changed as well alongside ILE. 
Results from Table 3 indicate a SID-ILE:SID-LYS requirement ratio of $74 \%$.

The SID-ILE requirement for dietary SID-ILE for EM production was also estimated directly on the pooled data from Mannion et al. and from Huyghebaert et al.. In this case we excluded the highest SID-ILE observations that did not result in meaningful increases in EM (i.e. less than $0.025 \mathrm{~g}$ EM per mg of SID-ILE supply) (Fig. 2). Including also body weight as a variable besides EM (not allowing for an intercept value) resulted in an estimate for body weight that was not significant and therefore was not included in the model.

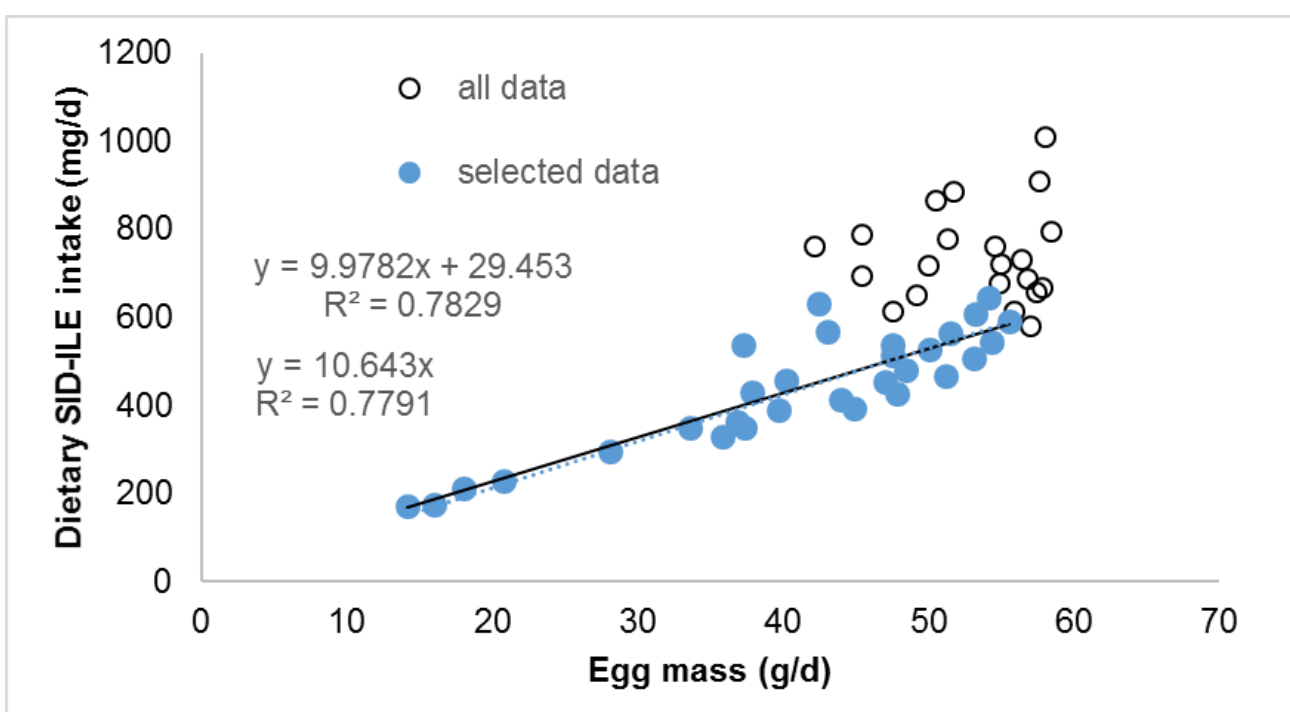

Figure 1. Relationship between egg mass produced (mg/d) and dietary SID-ILE for the pooled dataset of Huyghebaert et al. (1991) and Mannion et al. (1993). Regression equation is based on the selected data of the pooled (excluding the highest SID-ILE observations that did not result in meaningful increases in EM (i.e. less than $0.025 \mathrm{~g}$ increase in egg mass produced per mg of SID-ILE supply)).

Just as in Figure 1, the requirement for dietary SID-ILE for EM production was directly estimated on the pooled data from Mannion et al. and from Huyghebaert et al. but then results from trials 12 and 13 from the study of Mannion et al. were excluded due to the low maximum egg production rates for these two trials. Furthermore, just as was done in Figure 1, the highest SID-ILE observations were excluded that did not result in meaningful increases in EM (i.e. less than $0.025 \mathrm{~g}$ EM per mg of SID-ILE supply) (Fig. 2). 


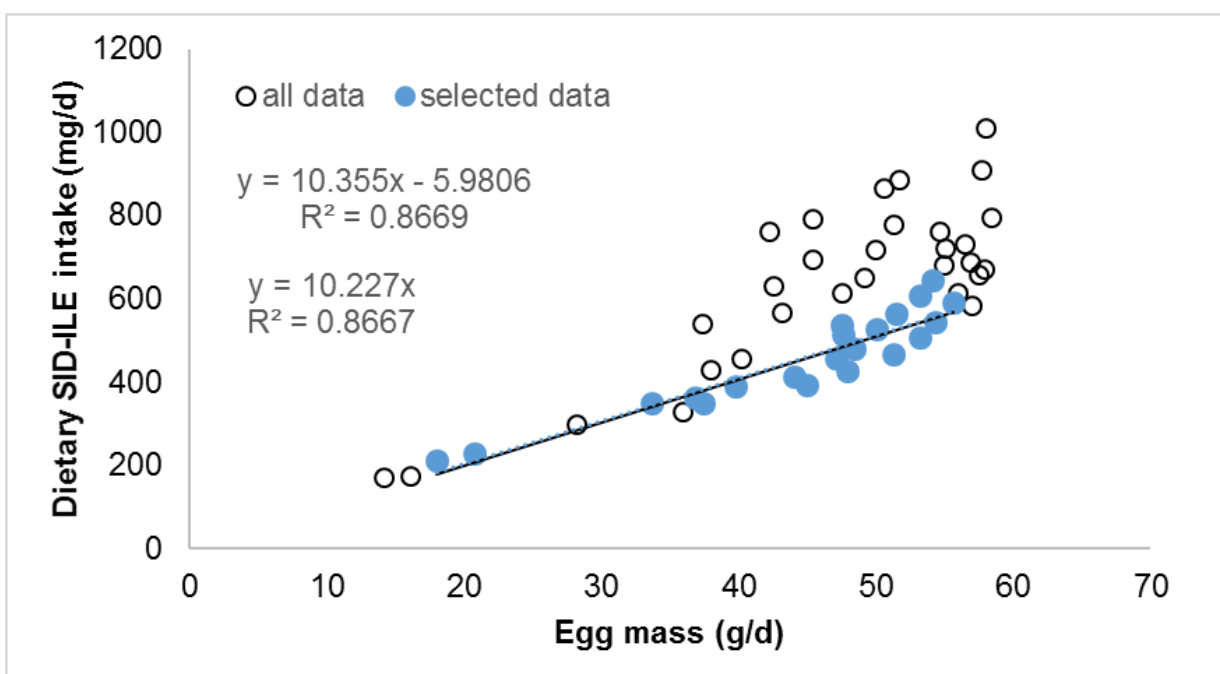

Figure 2. Relationship between egg mass produced $(\mathrm{mg} / \mathrm{d})$ and dietary SID-ILE for the pooled dataset of Huyghebaert et al. (1991) and Mannion et al. (1993) but excluding results from trials 12 and 13 from the study of Mannion et al. due to the low maximum egg production rates for these two trials. Regression equation is based on the selected data of the pooled (excluding the highest SID-ILE observations that did not result in meaningful increases in EM (i.e. less than $0.025 \mathrm{~g}$ increase in egg mass produced per $\mathrm{mg}$ of SID-ILE supply)).

The regression formula shown in Figure 2 shows a dietary SID-ILE requirement of $10.2 \mathrm{mg}$ per $\mathrm{g}$ of EM produced. This estimate is very similar to the observed average optimal SID-ILE level of $10.3 \mathrm{mg}$ per $\mathrm{g}$ of EM produced.

In Table 4 the estimated optimal SID-ILE requirements for maximum EM expressed in $\mathrm{mg} / \mathrm{d}$ and as a percentage of the diet for maximum EM at various egg production rates are given based on the average model estimated SID-ILE requirement of $11.1 \mathrm{mg}$ per gram of EM produced as shown in Table 2. 
Table 4. Estimated optimal SID-ILE requirements for maximum EM expressed in $\mathrm{mg} / \mathrm{d}$ and as a percentage of the diet for maximum EM at various egg production rates based on the average model estimated SID-ILE requirement of $11.1 \mathrm{mg}$ per gram of EM produced as shown in Table 2. The calculated feed intake required for an average egg weight of $60 \mathrm{~g}$ and at egg production rates of 90 and $95 \%$ are based on the assumptions presented as a footnote $\left({ }^{\star}\right)$ underneath this Table.

\begin{tabular}{|c|c|c|c|c|c|c|c|c|c|c|}
\hline \multirow[b]{3}{*}{ BW $(\mathrm{kg})$} & \multicolumn{2}{|c|}{$\begin{array}{r}\text { Feed intake } \\
(\mathrm{g} / \mathrm{d}) \\
\end{array}$} & \multicolumn{2}{|c|}{$\begin{array}{r}\text { Egg mass } \\
(\mathrm{g} / \mathrm{d}) \\
\end{array}$} & \multicolumn{2}{|c|}{$\begin{array}{r}\text { SID-ILE } \\
(\mathrm{mg} / \mathrm{d}) \\
\end{array}$} & \multicolumn{2}{|c|}{$\begin{array}{r}\text { Dietary SID- } \\
\text { ILE (\%) }\end{array}$} & \multicolumn{2}{|c|}{$\begin{array}{l}\text { SID-ILE:SID- } \\
\text { LYS ratio** }\end{array}$} \\
\hline & \multicolumn{10}{|c|}{ Egg production rate (\%) } \\
\hline & 90 & 95 & 90 & 95 & 90 & 95 & 90 & 95 & 90 & 95 \\
\hline 1.5 & 112 & 115 & 54 & 57 & 599 & 633 & 0.537 & 0.551 & 82 & 80 \\
\hline 1.6 & 114 & 117 & 54 & 57 & 599 & 633 & 0.524 & 0.539 & 82 & 80 \\
\hline 1.7 & 117 & 120 & 54 & 57 & 599 & 633 & 0.512 & 0.526 & 82 & 80 \\
\hline 1.8 & 120 & 123 & 54 & 57 & 599 & 633 & 0.501 & 0.515 & 82 & 80 \\
\hline 1.9 & 122 & 125 & 54 & 57 & 599 & 633 & 0.490 & 0.504 & 82 & 80 \\
\hline 2.0 & 125 & 128 & 54 & 57 & 599 & 633 & 0.480 & 0.494 & 82 & 80 \\
\hline
\end{tabular}

${ }^{*}$ Feed intake is calculated based on: a feed with a MElh content of $11.8 \mathrm{MJ} / \mathrm{kg}$, a requirement of $12.1 \mathrm{~kJ}$ per $\mathrm{g}$ egg mass, a maintenance requirement of $435 \mathrm{~kJ} M E$ per $\mathrm{kg} \mathrm{MBW}\left(\mathrm{BW}^{\wedge} 0.75\right)$, a requirement of $21.5 \mathrm{~kJ}$ ME per gram BWG, a daily BWG of $1.5 \mathrm{~g}$, and $9.5 \mathrm{~kJ}$ ME per kg BW per unit decrease in ${ }^{\circ} \mathrm{C}$ below $25{ }^{\circ} \mathrm{C}$ and a daily temperature of $22 \stackrel{\circ}{ } \mathrm{C}$.

${ }^{* *}$ The optimal SID-ILE:SID-LYS ratio for maximum EM is calculated based on the ratio between SID-ILE intake (SID-ILE requirements calculated as $11.1 \mathrm{mg}$ per gram of EM produced) and SID-LYS intake which is based on formula [F8] described in CVB documentation report nr. 69.

It is not easy to select a SID-ILE:SID-LYS requirement ratio. Based on average data from titration and dilution studies optimal SID-ILE:SID-LYS ratios may be 91\% (Table 2), 11.1 $12.3 \mathrm{mg}$ SID-ILE per gram of egg mass (Table 2) resulting in SID-ILE:SID-LYS ratios of 80 to $89 \%$ or around $10.3 \mathrm{mg}$ SID-ILE per gram of EM when choosing the approach shown in Figure 2 or when using the observed average optimal SID-ILE requirement per $g$ of EM resulting in a SID-ILE:SID-LYS requirement ratio of $74 \%$. The high ratio of $91 \%$ reported in Table 2 can be explained by the fact that low SID-LYS levels were used in the titration trials (on average $0.578 \%$ resulting in a high efficiency in which dietary lysine was converted into EM of $12.2 \mathrm{mg}$ SID-LYS per $\mathrm{g}$ of EM). For example, when using the relation F8 described in CVB Documentation report $\mathrm{nr}$. 69 an average SID-LYS of $13.4 \mathrm{mg}$ per $\mathrm{g}$ of egg mass would be expected. Using the SID-LYS requirement as predicted by formula F8 in CVB Documentation report nr. 69 the average SID-ILE:SID-LYS ratio of the titration experiments would become $84 \%$,

In Figure 3 the relationship between dietary SID-ILE intake $(\mathrm{mg} / \mathrm{d})$ and egg mass production $(\mathrm{g} / \mathrm{d} / \mathrm{hen})$ for the various trials are presented. The vertical lines represent the SID-ILE intake required for an EM production of $57 \mathrm{~g}$ and assuming SID-ILE:SID-LYS requirement ratios of $91 \%, 80 \%$ and $74 \%$. 


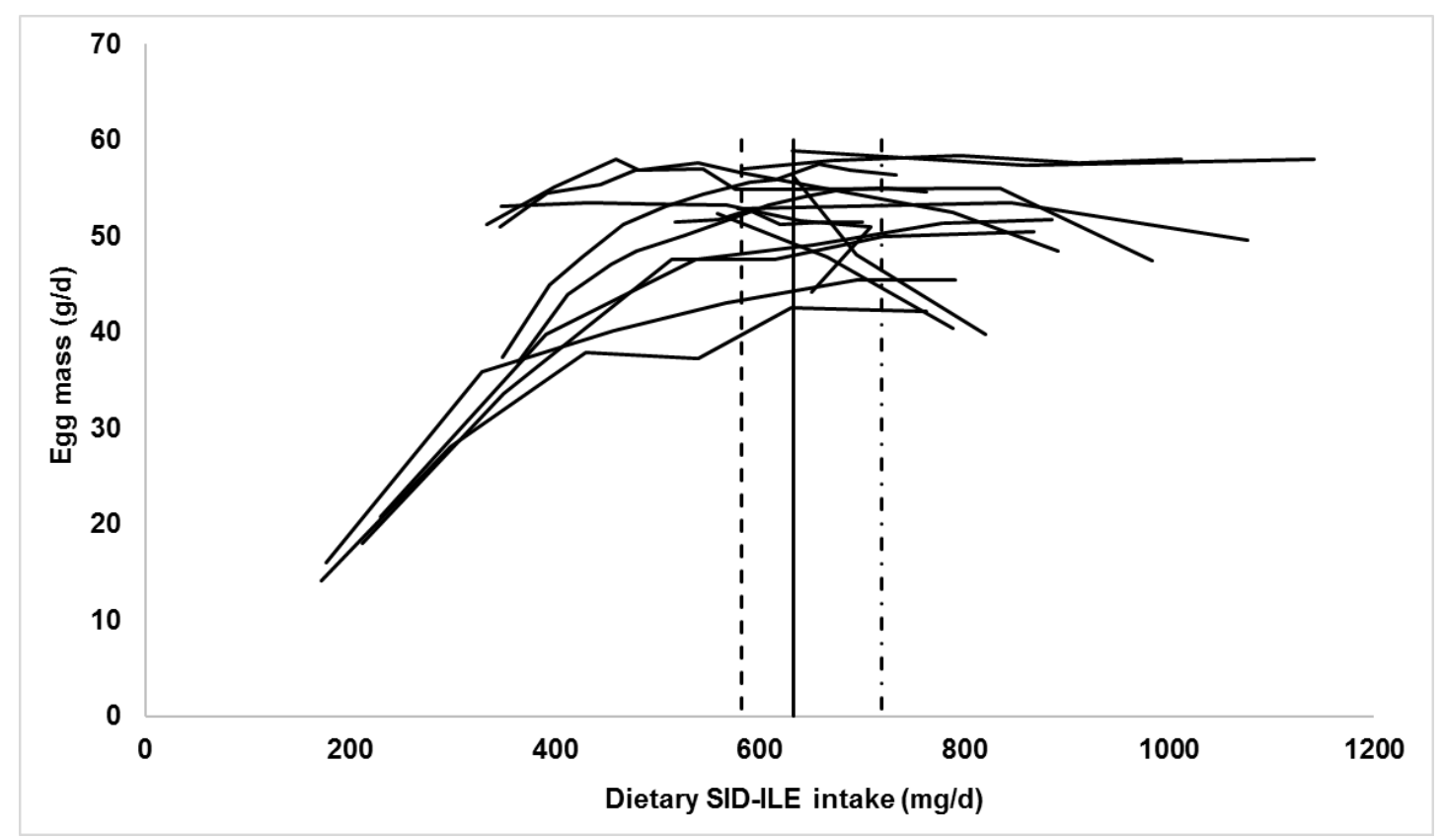

Figure 3. Relationship between dietary SID-ILE intake $(\mathrm{mg} / \mathrm{d})$ and egg mass production ( $\mathrm{g} / \mathrm{d} / \mathrm{hen})$. Based on average data from titration and dilution studies optimal SID-ILE:SID-LYS ratios may be $91 \%$ (vertical dash dotted line), $11.1 \mathrm{mg}$ SID-ILE per gram of egg mass resulting in a SID-ILE:SID-LYS ratio of $80 \%$ (vertical solid line) or around $10.3 \mathrm{mg}$ SID-ILE per gram of egg mass when choosing the approach shown in Figure 2 resulting in a SIDILE:SID-LYS requirement ratio of $74 \%$ (dashed line). 


\section{Conclusions}

It is concluded that it is most prudent to estimate requirement estimates of dietary SID-ILE on the titration studies and not on the dilution studies as the dietary protein levels in the dilution studies were much higher than observed in practice. These high dietary protein levels used in the dilution studies might affect the requirement estimates for SID-ILE. It is furthermore concluded that it seems not wise to use the estimated SID-ILE : SID-LYS requirement ratios that are based on the titration studies due to the low dietary SID-LYS concentrations used in the test diets resulting in high efficiencies in which dietary lysine was converted into EM. Therefore it is concluded that it is best to base the dietary SID-ILE requirement for laying hens on a SID-ILE requirement ratio of $11.1 \mathrm{mg}$ per $\mathrm{g}$ of EM. This requirement is the average estimated SID-ILE requirement ratio for maximum EM per $g$ of egg mass based on the titration studies as presented in Table 2. This requirement results in a SID-ILE:SID-LYS requirement ratio of $80 \%$ for a hen producing $57 \mathrm{~g}$ of EM. 


\section{List of studies included in the meta-analysis}

da Rocha, T. C., Donzele, J. L., Gomes, P. C., Mello, H. H. C., Troni, A. R. \& Viana, G. S. 2013. Ideal digestible isoleucine: Digestible lysine ratio in diets for laying hens aged 24-40 weeks. 42, 780-784.

de Carvalho Mello, H. H., Gomes, P. C., da Rocha, T. C., Donzele, J. L., de Almeida, R. L., Troni, A. R., de Carvalho, B. R. \& da Silva Viana, G. 2012. Determination of digestible isoleucine: Lysine ratio in diets for laying hens aged 42-58 weeks. Revista Brasileira de Zootecnia, 41, 1313-1317.

Dong, X. Y., Azzam, M. M. M. \& Zou, X. T. 2016. Effects of dietary L-isoleucine on laying performance and immunomodulation of laying hens. Poultry Science, 95, 2297-2305.

Huyghebaert, G., Groote, G. D., Butler, E. A. \& Morris, T. R. 1991. optimum isoleucine requirement of laying hens and the effect of age. British Poultry Science, 32, 471-481.

Mannion, P. F., Young, R. A., Fuelling, D. E. \& Barram, K. M. 1993. Responses of laying hens to diets differing in isoleucine content. Australian Journal of Agricultural Research, 44, 1147-1160.

Peganova, S. \& Eder, K. 2002. Studies on requirement and excess of isoleucine in laying hens. 81, 1714-1721.

Peganova, S. \& Eder, K. 2003. Interactions of various supplies of isoleucine, valine, leucine and tryptophan on the performance of laying hens. Poultry Science, 82, 100-105.

Shivazad, M., Harms, R. H., Russell, G. B., Faria, D. E. \& Antar, R. S. 2002. Re-evaluation of the isoleucine requirement of the commercial layer. Poultry Science, 81, 1869-1872.

\section{References}

Blok, M. C. and R. A. Dekker. 2017. Table 'Standardized ileal digestibility of amino acids in feedstuffs for poultry'. CVB Documentation report nr. 61.

Krimpen, M. M., T. Veldkamp, J. W. van Riel, V. Khaksar, H. Hashemipour, M.C. Blok, and W. Spek. 2015. Estimating requirements for apparent faecal and standardised ileal digestible amino acids in laying hens by a meta-analysis approach.

Robbins, K. R., Saxton, A. M. \& Southern, L. L. 2006. Estimation of nutrient requirements using broken-line regression analysis. Journal of Animal Science, 84, E155-E165.

Spek, J. W. 2018. Standardized ileal digestible lysine requirement for laying hens. CVB Documentation report nr. 69. 


\section{Appendix A. Relationship between dietary SID-ILE supply and performance parameters FCR and EM for the various titration trials including the estimated SID-ILE requirements based on the quadratic broken-line model}

The letter 'a' behind the trial number (shown in the first column) means the model is fitted on all observations except the observations with the lowest dietary SID-ILE level. If no letter is shown behind the trial number it means that the model is fitted based on all observations of the trial.

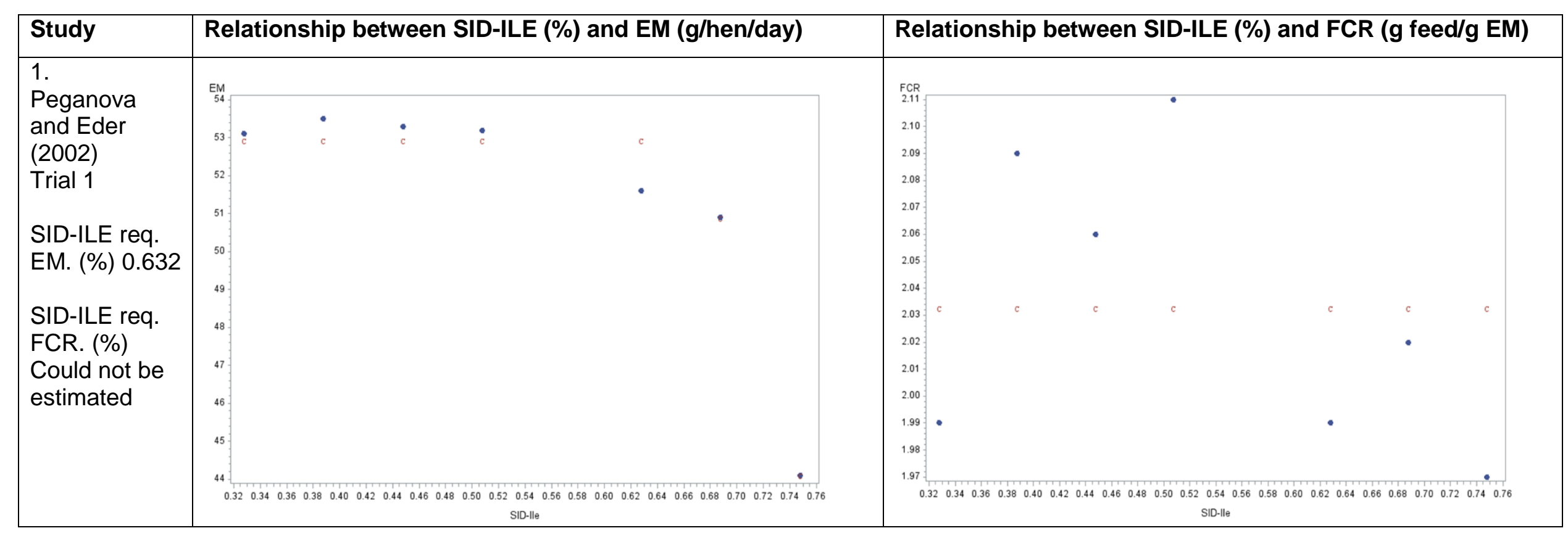




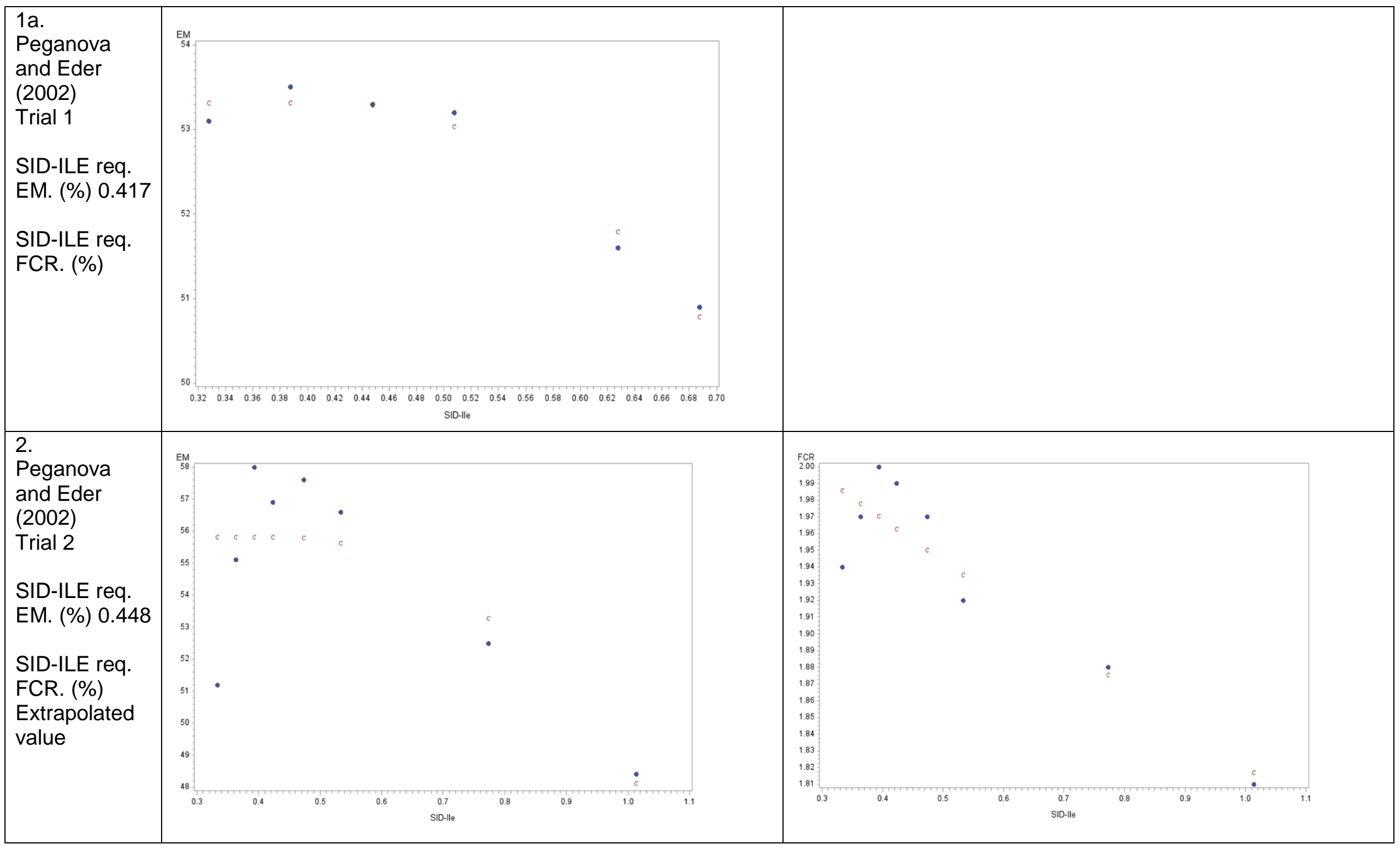




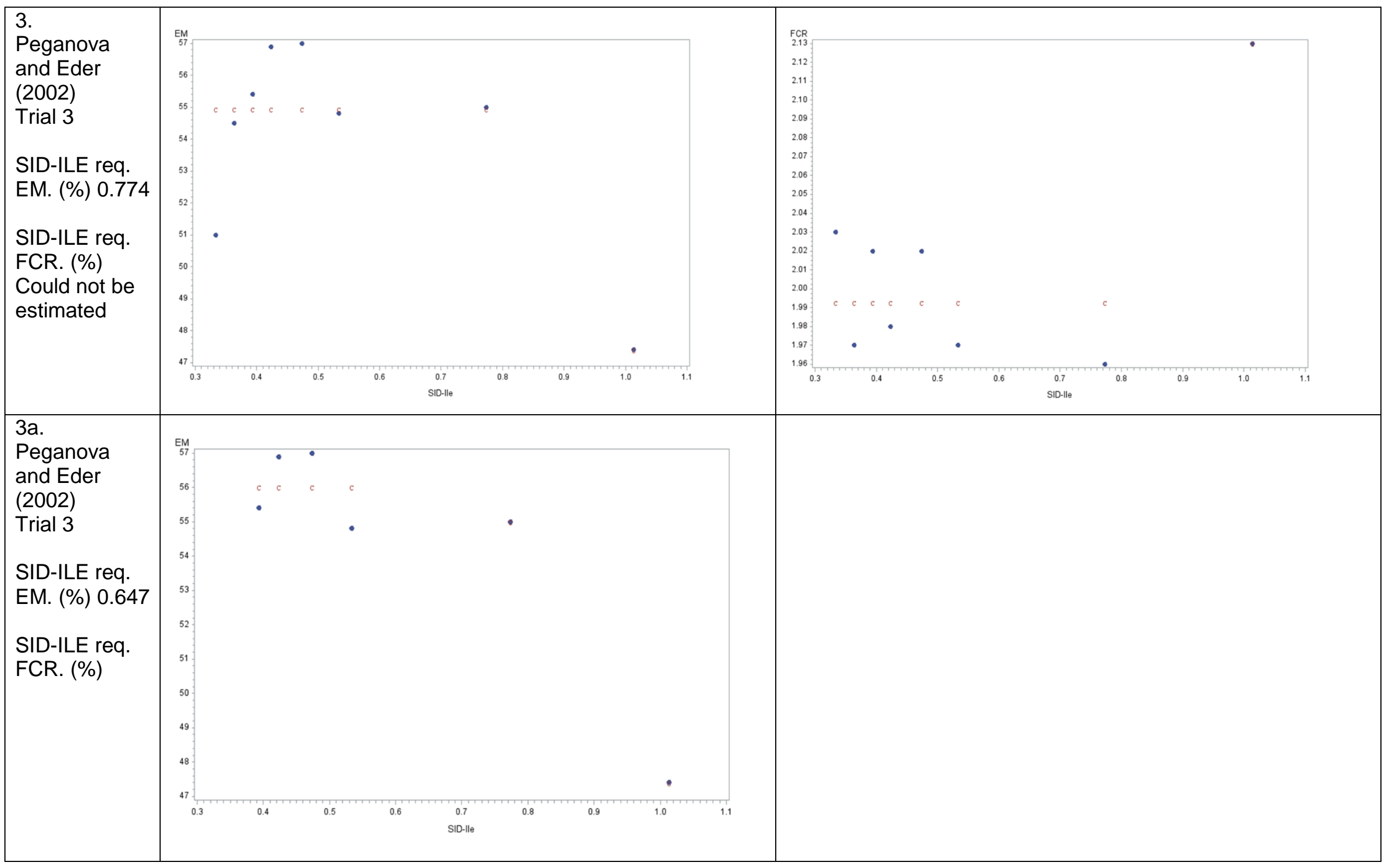




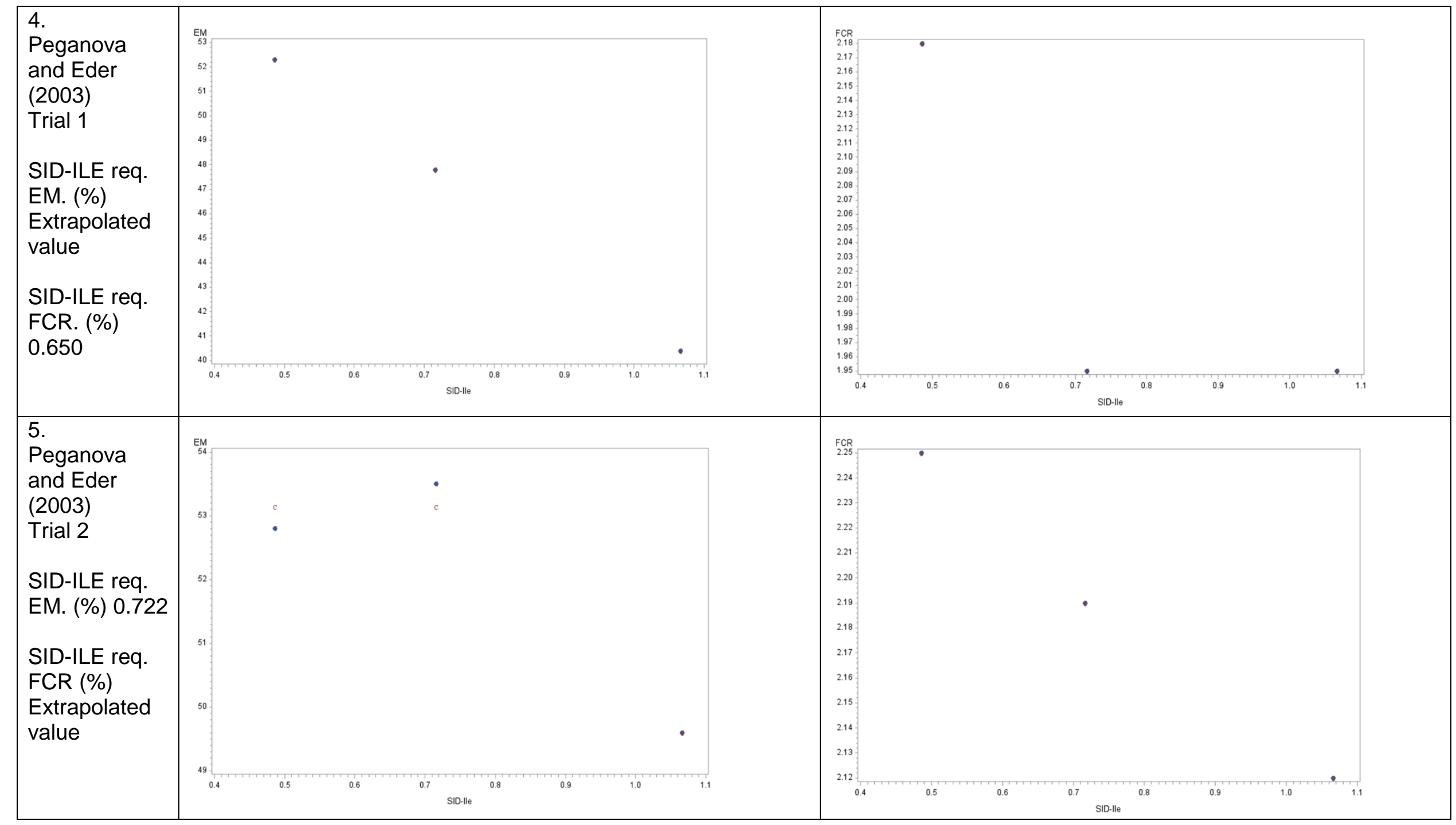




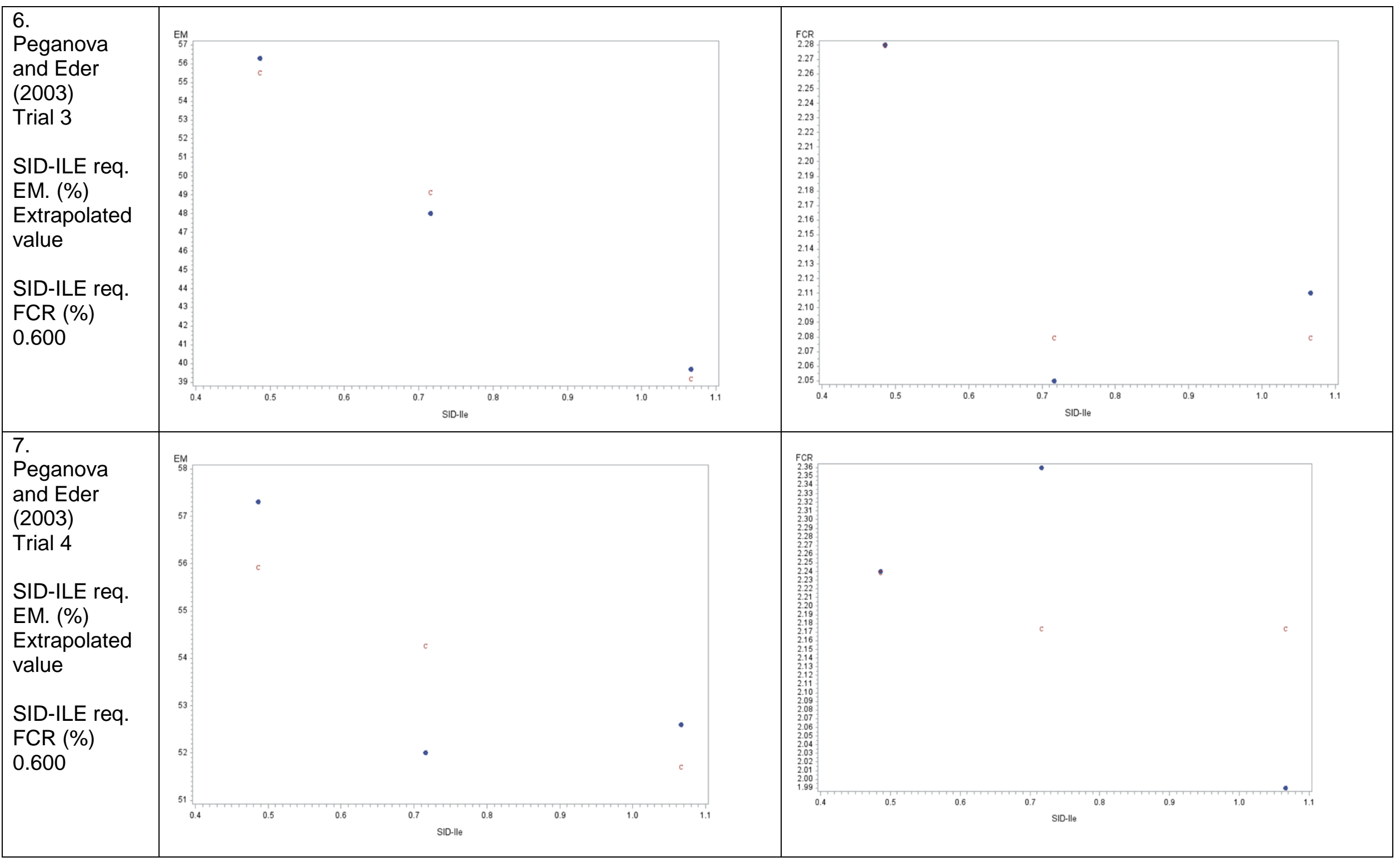




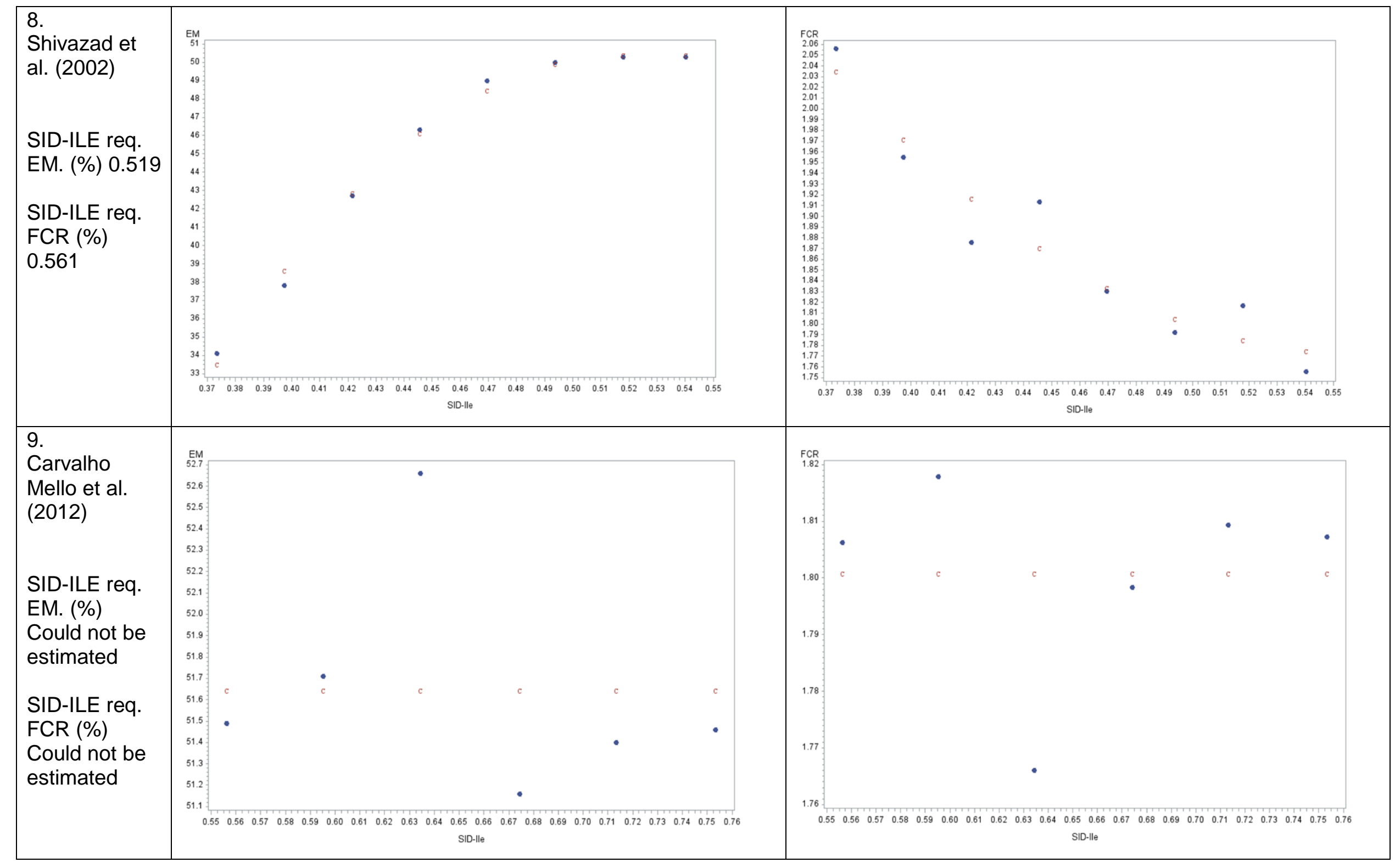




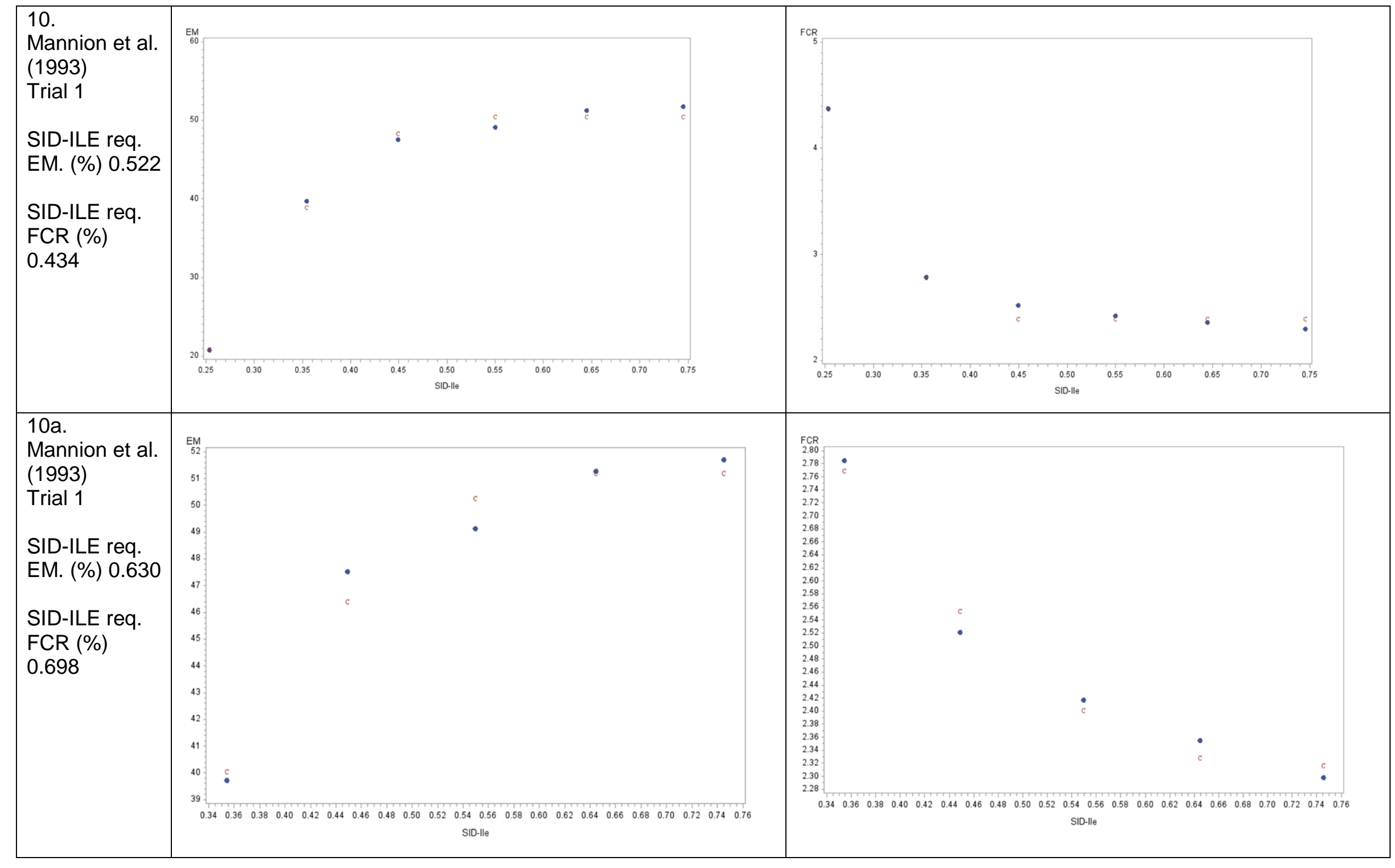




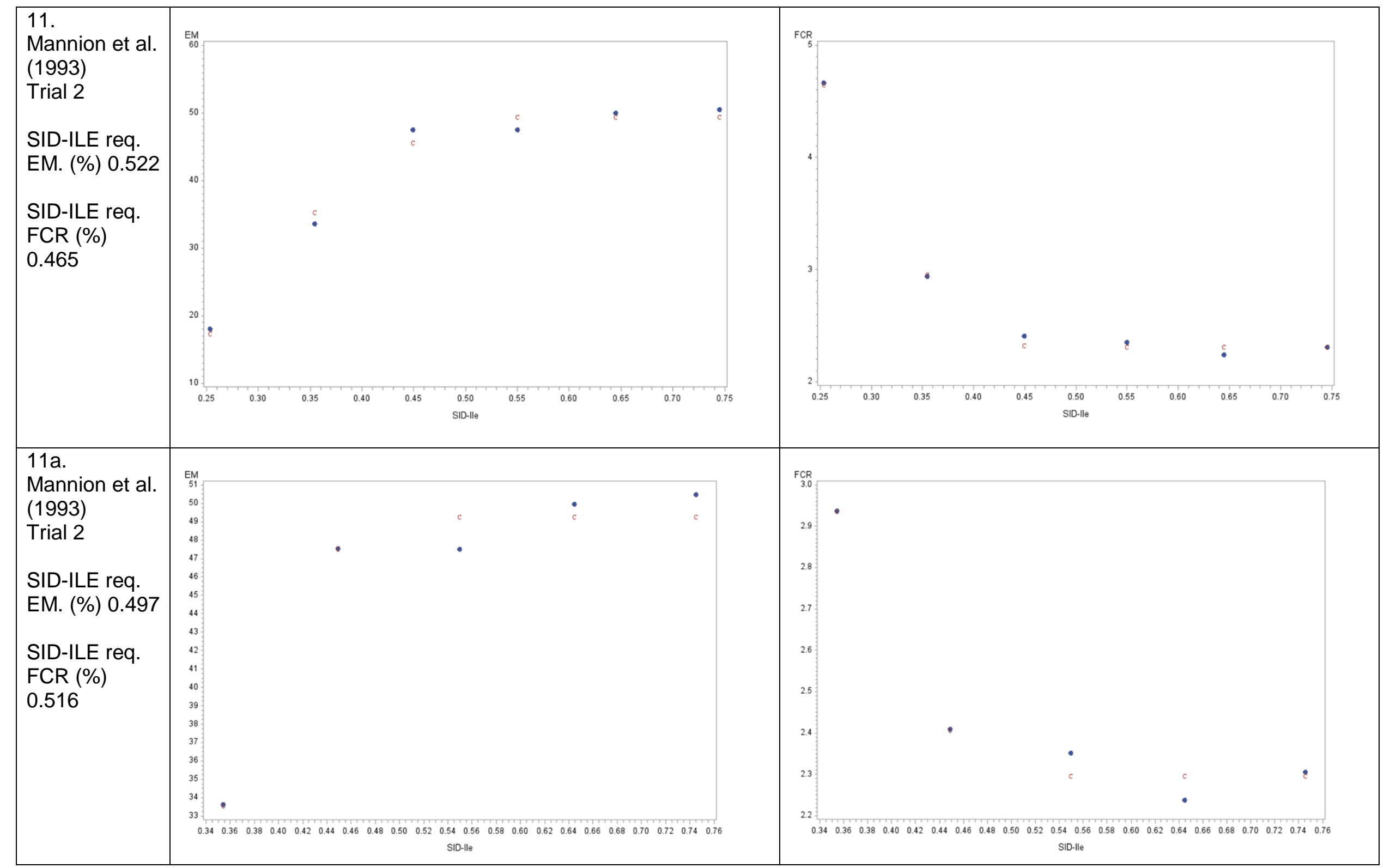




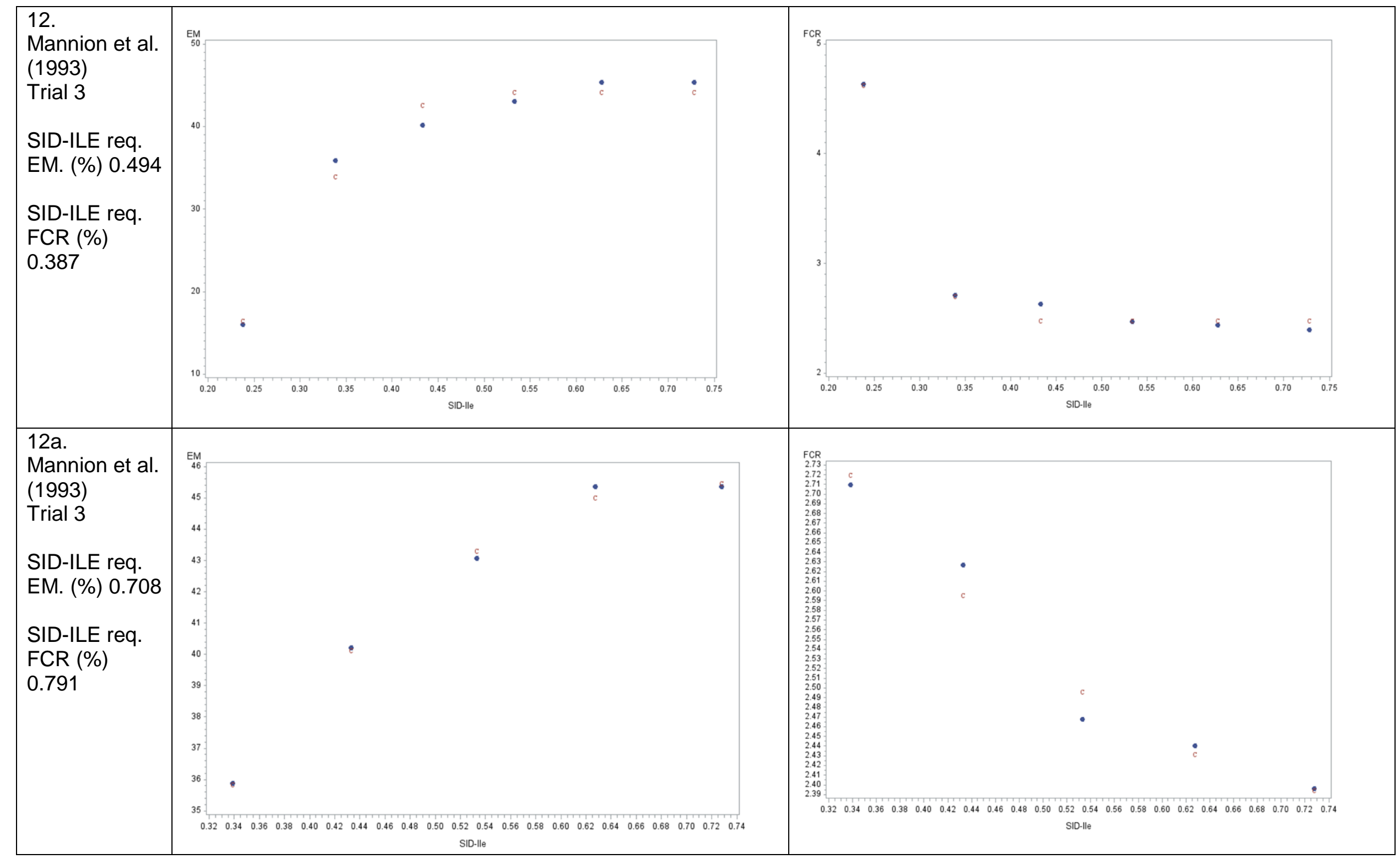




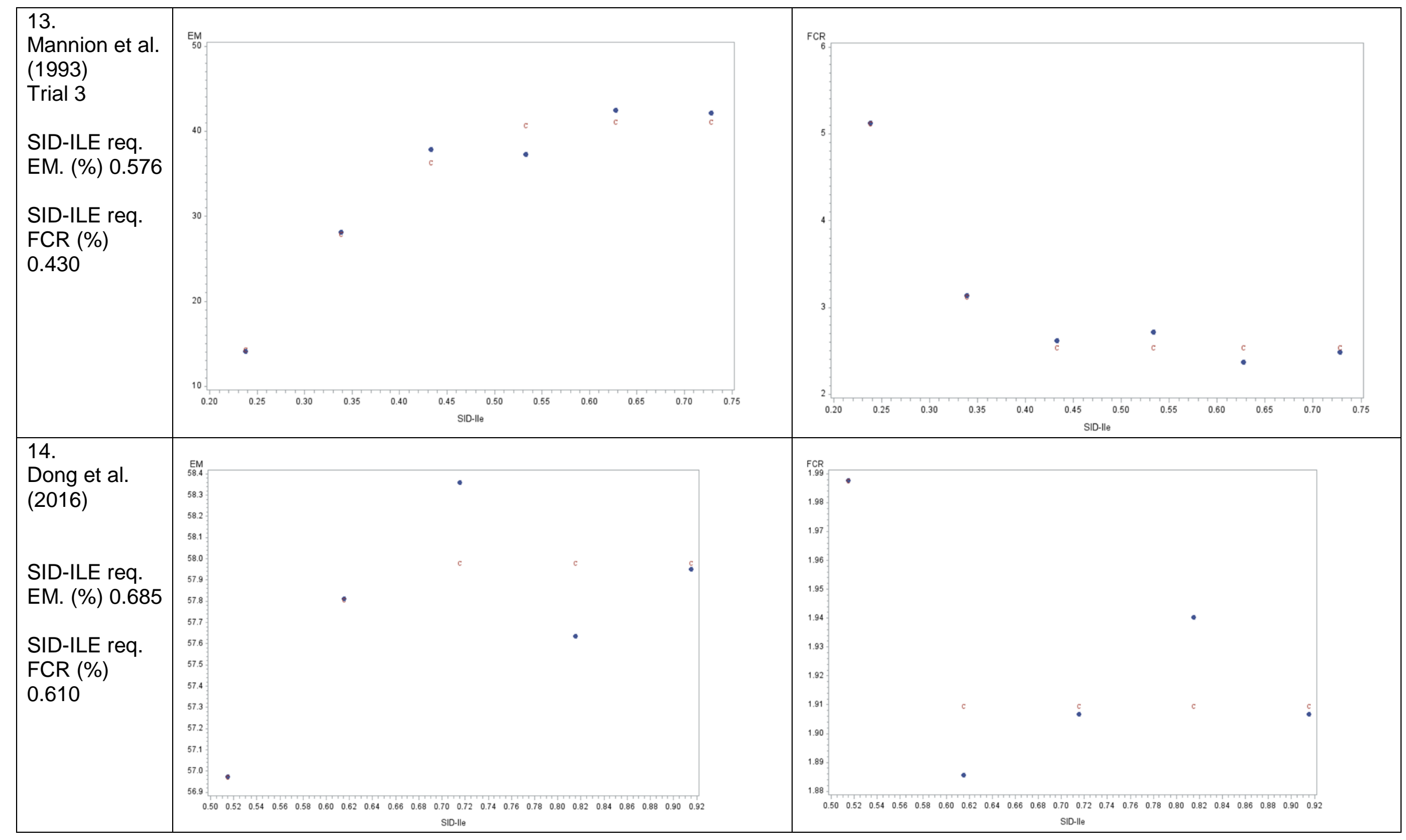




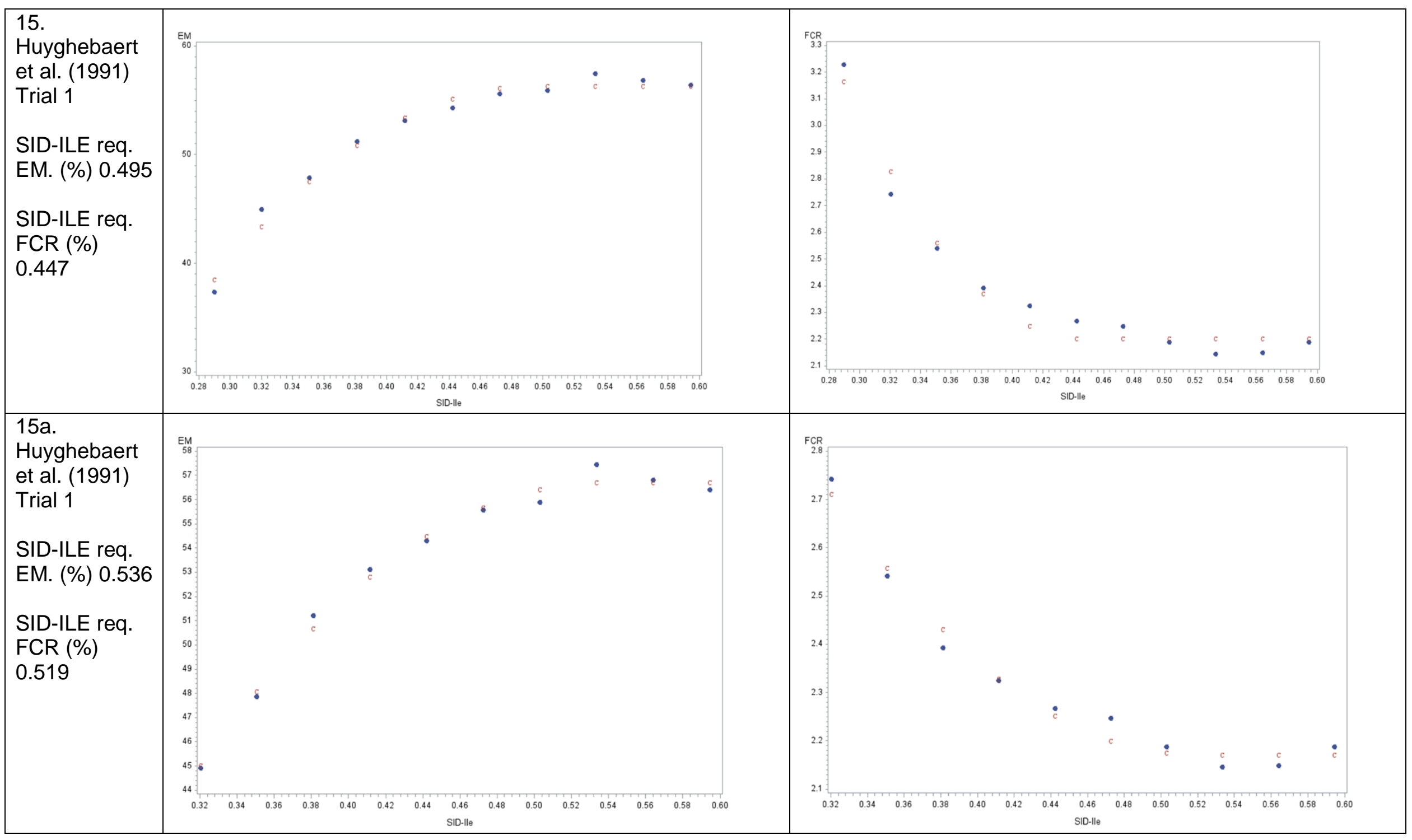




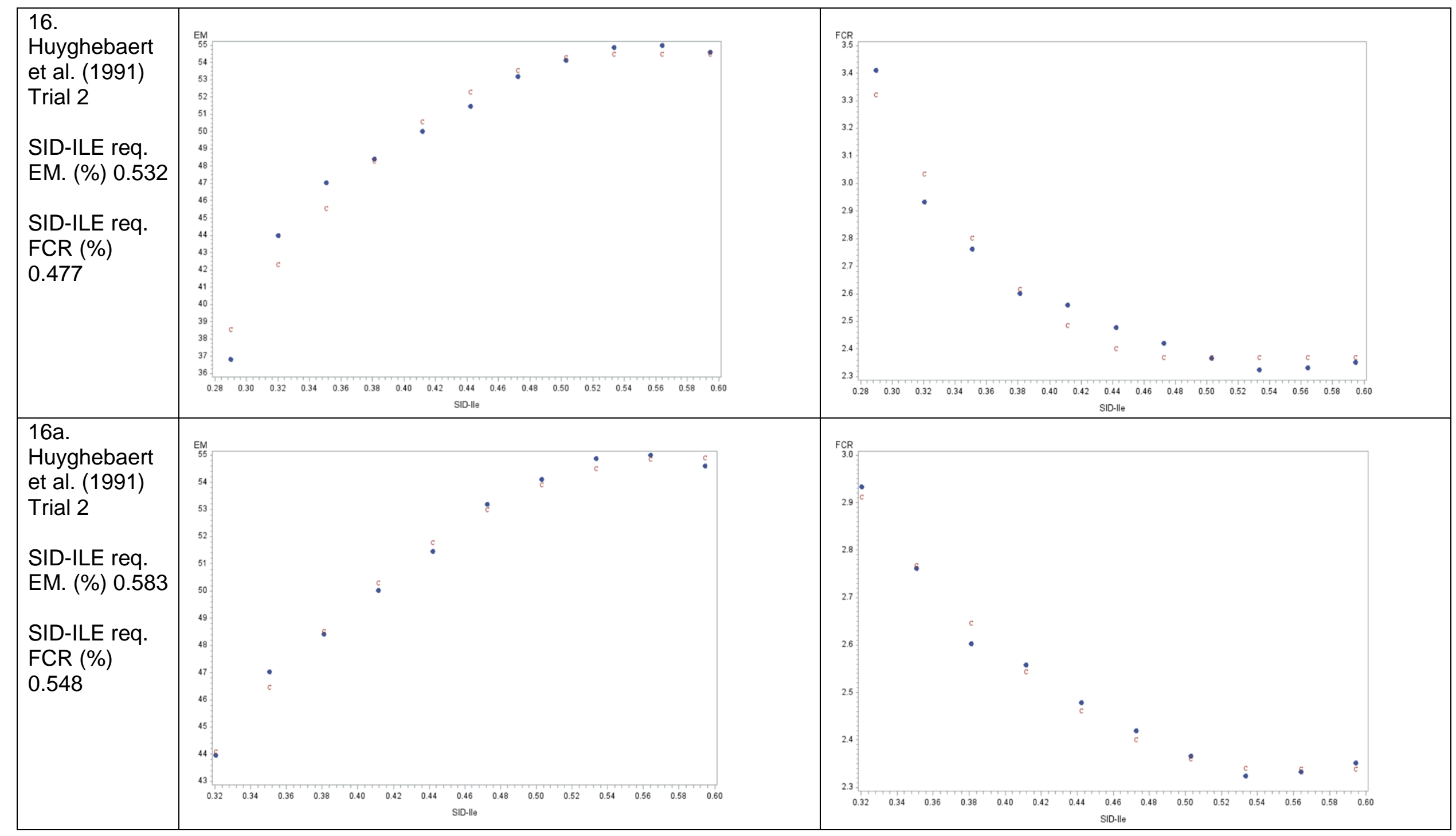




\section{Appendix B. SID-ILE model estimates for minimum FCR and maximum EM}

SID-ILE model estimates for minimum FCR. Values of $\mathbf{R}$ that are bold are extrapolated estimated values. The letter ' $a$ ' behind the trial number (shown in the first column) means the model is fitted on all observations except the first observation with the lowest dietary SID-ILE level. If no letter is shown behind the trial number it means that the model is fitted based on all observations of the trial.

\begin{tabular}{|c|c|c|c|c|c|c|c|}
\hline $\begin{array}{l}\text { Trial } \\
\text { nr. }\end{array}$ & $\begin{array}{r}\text { Estimate } \\
\mathrm{L}\end{array}$ & $\begin{array}{r}\text { Std. Err. } \\
\text { L }\end{array}$ & $\begin{array}{r}\text { Estimate } \\
\mathbf{R}\end{array}$ & $\begin{array}{r}\text { Std. Err. } \\
\mathbf{R}\end{array}$ & $\begin{array}{r}\text { Estimate } \\
\text { U }\end{array}$ & $\begin{array}{r}\text { Std. Err. } \\
\text { U }\end{array}$ & $\mathbf{R}^{2}$ \\
\hline \multicolumn{8}{|l|}{1} \\
\hline \multicolumn{8}{|l|}{$1 a$} \\
\hline 2 & 0.57 & 31.565 & 11.406 & 254 & 0.0 & 0.3 & 0.844 \\
\hline 3 & & & & & & & \\
\hline \multicolumn{8}{|l|}{$3 a$} \\
\hline 4 & 1.95 & 0.000 & 0.650 & . & -8.6 & 0.0 & 1.000 \\
\hline 5 & 2.06 & & 1.844 & & -0.1 & & 1.000 \\
\hline 6 & 2.08 & 0.021 & 0.600 & & -15.4 & 2.8 & \\
\hline 7 & 2.18 & 0.185 & 0.600 & & -5.0 & 24.8 & \\
\hline 8 & 1.77 & 0.044 & 0.561 & 0.0653 & -7.5 & 4.6 & 0.914 \\
\hline \multicolumn{8}{|l|}{9} \\
\hline 10 & 2.40 & 0.048 & 0.434 & 0.0193 & -60.6 & 13.4 & 0.991 \\
\hline $10 a$ & 2.32 & 0.032 & 0.698 & 0.0634 & -3.8 & 1.4 & 0.982 \\
\hline 11 & 2.32 & 0.037 & 0.465 & 0.0139 & -52.5 & 7.1 & 0.997 \\
\hline $11 \mathrm{a}$ & 2.30 & 0.033 & 0.516 & 0.0338 & -24.3 & 10.2 & 0.979 \\
\hline 12 & 2.48 & 0.050 & 0.387 & 0.0174 & -97.4 & 22.9 & 0.992 \\
\hline $12 \mathrm{a}$ & 2.39 & 0.052 & 0.791 & 0.1440 & -1.6 & 0.9 & 0.973 \\
\hline 13 & 2.55 & 0.076 & 0.430 & 0.0249 & -70.3 & 18.9 & 0.987 \\
\hline 14 & 1.91 & 0.011 & 0.610 & & -8.6 & 2.8 & 0.760 \\
\hline 15 & 2.20 & 0.025 & 0.447 & 0.0156 & -39.2 & 8.6 & 0.972 \\
\hline $15 a$ & 2.17 & 0.016 & 0.519 & 0.0181 & -13.7 & 2.7 & 0.980 \\
\hline 16 & 2.37 & 0.030 & 0.477 & 0.0204 & -27.2 & 6.5 & 0.966 \\
\hline $16 a$ & 2.34 & 0.014 & 0.548 & 0.0149 & -11.1 & 1.5 & 0.990 \\
\hline
\end{tabular}


SID-ILE model estimates for maximum EM. Values of $\mathbf{R}$ that are bold are extrapolated estimated values. The letter ' $a$ ' behind the trial number (shown in the first column) means the model is fitted on all observations except the first observation with the lowest dietary SID-ILE level. If no letter is shown behind the trial number it means that the model is fitted based on all observations of the trial.

\begin{tabular}{|c|c|c|c|c|c|c|c|}
\hline $\begin{array}{l}\text { Trial } \\
\text { nr. }\end{array}$ & $\begin{array}{r}\text { Estimate } \\
\mathrm{L}\end{array}$ & $\begin{array}{r}\text { Std. Err. } \\
\text { L }\end{array}$ & $\begin{array}{r}\text { Estimate } \\
\mathbf{R} \\
\end{array}$ & $\begin{array}{r}\text { Std. Err. } \\
\mathbf{R}\end{array}$ & $\begin{array}{r}\text { Estimate } \\
\mathbf{U}\end{array}$ & $\begin{array}{r}\text { Std. Err. } \\
\text { U }\end{array}$ & $\mathbf{R}^{2}$ \\
\hline 1 & 53 & 0.3 & 0.632 & 0.0216 & 663 & 260 & 0.966 \\
\hline $1 a$ & 53 & 0.1 & 0.417 & 0.0551 & 35 & 14 & 0.973 \\
\hline 2 & 56 & 1.1 & 0.448 & 0.3964 & 24 & 35 & 0.614 \\
\hline 3 & 55 & 0.8 & 0.774 & & 132 & 37 & 0.674 \\
\hline $3 a$ & 56 & 0.5 & 0.647 & 0.1133 & 64 & 40 & 0.943 \\
\hline 4 & 85 & & -2.995 & & 3 & & 1.000 \\
\hline 5 & 53 & 0.4 & 0.722 & & 30 & 5 & 0.972 \\
\hline 6 & 208 & & -10.598 & & 1 & & 0.984 \\
\hline 7 & 119 & & -17.100 & & 0 & & 0.535 \\
\hline 8 & 50 & 0.3 & 0.519 & 0.0079 & 801 & 89 & 0.995 \\
\hline 9 & & & & & & & \\
\hline 10 & 51 & 0.7 & 0.522 & 0.0237 & 410 & 75 & 0.993 \\
\hline $10 a$ & 51 & 0.8 & 0.630 & 0.0632 & 147 & 68 & \\
\hline 11 & 50 & 1.2 & 0.552 & 0.0365 & 359 & 92 & 0.985 \\
\hline $11 a$ & 49 & 0.9 & 0.497 & 0.0365 & 772 & 393 & 0.974 \\
\hline 12 & 44 & 1.2 & 0.494 & 0.0402 & 424 & 138 & 0.978 \\
\hline $12 a$ & 45 & 0.3 & 0.708 & 0.0267 & 70 & 10 & 0.997 \\
\hline 13 & 41 & 1.5 & 0.576 & 0.0603 & 253 & 86 & 0.971 \\
\hline 14 & 58 & 0.2 & 0.685 & 0.1420 & 35 & 59 & 0.744 \\
\hline 15 & 56 & 0.4 & 0.495 & 0.0156 & 425 & 70 & 0.983 \\
\hline $15 a$ & 57 & 0.2 & 0.536 & 0.0130 & 250 & 32 & 0.991 \\
\hline 16 & 55 & 0.6 & 0.532 & 0.0248 & 272 & 59 & 0.971 \\
\hline $16 a$ & 55 & 0.3 & 0.583 & 0.0152 & 157 & 18 & 0.993 \\
\hline
\end{tabular}

